\title{
Effect of dietary flavonols on oestrogen receptor transactivation and cell death induction
}

\author{
Lai K. Leung ${ }^{1,2 *}$, Lai See $\mathrm{Po}^{2}$, Tak Yee Lau ${ }^{2}$ and Yee Man Yuen ${ }^{2}$ \\ ${ }^{1}$ Food and Nutritional Sciences Programme and \\ ${ }^{2}$ Department of Biochemistry, The Chinese University of Hong Kong, Shatin, N.T., Hong Kong
}

(Received 15 July 2003 - Revised 4 February 2004 - Accepted 10 February 2004)

\begin{abstract}
Consumption of fruits and vegetables has been associated with cancer prevention; flavonoids are widely distributed in plant foods and considered to be the active ingredients. Quercetin and kaempferol are two of the most commonly found dietary flavonols, and have been reported to prevent cancer. We have previously reported that the isoflavone genistein and the flavone baicalein exert differential actions on the oestrogen receptor (OR) $\alpha$ in HepG2 cells. Because of the structural resemblance to both isoflavone and flavone, we examined the effects of these dietary flavonols on $\mathrm{OR} \alpha-$ and OR $\beta$-specific transactivations and their subsequent involvement in inducing MCF-7 cell death. In the present study, both quercetin and kaempferol were able to compete for OR binding in a cell-free system and were agonistic to $\mathrm{OR} \alpha$ and $-\beta$ expressed in HepG2 cells, while some additive effect was observed in the oestrogen response element (ORE)-driven transcription when $17 \beta$-oestradiol was co-administered. Since the $b c l-2$ promoter contained two ORE, and ORE-driven transcriptional activity and Bcl-2 mRNA expression were increased by treatment with $10 \mu \mathrm{M}$-quercetin or kaempferol, it is possible that quercetin and kaempferol might up-regulate Bcl-2 expression through OR transactivation in MCF-7 cells. Cell death ELISA assay performed on MCF-7 cells indicated that an increase of apoptosis occurred at $25 \mu \mathrm{M}-$, but not $10 \mu \mathrm{M}-$, quercetin or kaempferol. Indirectly the results suggest that OR activation is not sufficient to induce apoptosis and that apoptosis is induced despite an increase in Bcl-2 expression.
\end{abstract}

Quercertin: Kaempferol: Cell death: Bcl-2: Oestrogen receptor

Flavonoids are a group of polyphenolic chemicals isolated from plants. They structurally resemble the human hormone oestrogen and are widely distributed in our diet (Hollman \& Katan, 1999). Women in Asian countries with a high phyto-oestrogen consumption suffer less from postmenopausal diseases, such as osteoporosis, CVD, and breast and endometrial cancers, than their counterparts in the West (Goodman et al. 1997; Ingram et al. 1997; Tham et al. 1998; Davis et al. 1999). Epidemiological studies have demonstrated that high phyto-oestrogen consumption is associated with a low incidence of breast cancer (Ingram et al. 1997); women at high risk of breast cancer are advised to take phyto-oestrogens to control the postmenopausal symptoms as well as to minimize their cancer risks (Lee et al. 2000), although the suggestion is still under scrutiny.

Flavonol is a major subclass of flavonoid, and quercetin and kaempferol are two of the most commonly found dietary flavonols (de Vries et al. 1998). In animal models quercetin has been reported to decrease the incidence of cancer in the small intestine (Akagi et al. 1995) and colon (Matsukawa et al. 1997). The anti-cancer mechanisms of these phytochemicals have been ascribed to their antioxidative nature and their ability to modulating drug-metabolizing enzymes.
Quercetin can modulate the expressions of cytochrome P450 (CYP) 1A1 and CYP1B1 (Chan et al. 2003), and kaempferol reduces the expression of CYP1A1 (Ciolino et al. 1999). These enzymes have been demonstrated to be crucial factors in biotransforming polycyclic aromatic hydrocarbons (Gonzalez, 2001).

Two types of oestrogen receptors (OR), which are now known as the $\alpha$ and $\beta$ isoforms, have differences in ligand specificity and tissue distribution (Kuiper et al. 1997). The difference offers an opportunity of developing specific OR modulators targeting bone lost, but not promoting cancers in the breast and endometrium (Dechering et al. 2000). Raloxifene is a newly developed specific OR modulator exhibiting oestrogenic properties in bone (Delmas et al. 1997) but anti-oestrogenic in the breast (Cummings et al. 1999), while the isoflavone genistein has been proposed to be a natural specific OR modulator (Linford \& Dorsa, 2002).

Programmed cell death or apoptosis is a process that controls the growth and development of organisms. Bcl-2 is the first protein identified to protect a cell from undergoing apoptosis (Reed, 1998; Gross et al. 1999). Many Bcl-2 protein homologues that are either pro- or anti-apoptotic have subsequently been discovered. Interactions 
among these proteins could determine the death or survival of a cell (Reed, 1998; Gross et al. 1999) and manipulating this process is a crucial part of cancer prevention and therapy (Lowe \& Lin, 2000).

Many flavonoids or their derivatives have been documented to be antagonistic to oestradiol-induced OR transactivation, such as kaempferide, flavone and apigenin (Collins-Burrow et al. 2000). Our laboratory has previously illustrated that baicalein, but not genistein, antagonizes the binding of $17 \beta$-oestradiol to OR $\alpha$ (Po et al. 2002a,b). The flavonols quercetin and kaempferol are structurally similar to either baicalein or genistein, so the interactions between the dietary flavonols and the two OR isoforms were investigated in the present study. In addition, quercetin has been reported to exert different effects on OR from genistein (Miodini et al. 1999) and antagonize the proliferation-stimulating activity of environmental oestrogens (Han et al. 2001). We hypothesized that these two natural-occurring flavonoids could antagonize $\operatorname{OR} \alpha$ and $-\beta$ and induce cell death.

\section{Methods}

\section{Chemicals}

Quercetin, kaempferol, genistein and $17 \beta$-oestradiol were purchased from Sigma Chemical Co. (St Louis, MO, USA). All other chemicals were purchased from Sigma if not stated.

\section{Oestrogen receptor $\alpha$ competitive binding assay}

An Oestrogen-Receptor $(\alpha)$ Competition Screening Kit was obtained from Wako Chemicals (Osaka, Japan) to quantify the competition between fluorescein-labelled oestradiol and flavonoids for $\mathrm{OR} \alpha$ binding. The flavonols were incubated with $10^{9} \mathrm{M}$-fluorescein-labelled oestradiol in a ninety-sixwell plate coated with recombinant $\mathrm{OR} \alpha$ for $2 \mathrm{~h}$. After flushing the wells with wash buffer, the fluorescence was read at excitation wavelength $480 \mathrm{~nm}$ and emission $530 \mathrm{~nm}$ by a fluorescence plate reader (FLUOstar Galaxy; BMG Labtechnologies Pty Ltd, Mount Eliza, Victoria, Australia).

\section{Cell culture}

The hepatocarcinoma cell line HepG2 was obtained from American Tissue Culture Collection (Rockville, MD, USA), the oestrogen receptor element (ORE)-Luc stably transfected cell line MELN from Dr $P$ Balaguer (INSERM, Montpellier, France) and the breast cancer cell line MCF-7 from Dr VC Jordan (Northwestern University, IL, USA). The cells were incubated in Phenol-Redfree Roswell Park Memorial Institute 1640 medium with $2 \mu \mathrm{mol} \mathrm{L-glutamine/1} \mathrm{(Sigma} \mathrm{Chemical} \mathrm{Co.),} 100000 \mathrm{U}$ penicillin/l, $100 \mathrm{~g}$ streptomycin/l and fetal bovine serum $(50 \mathrm{ml} / \mathrm{l}) \quad\left(\mathrm{Gibco}^{\mathrm{TM}}\right.$; Invitrogen Corporation, Rockville, MD, USA). The incubator was maintained at $37^{\circ} \mathrm{C}$ and $\mathrm{CO}_{2}$-air $(95: 5, \mathrm{v} / \mathrm{v})$. Three days before the beginning of experiments the cells were switched to the same media with charcoal dextran-treated fetal bovine serum $(50 \mathrm{~g} / \mathrm{l})$ (Hyclone; Logan, UT, USA) instead of fetal bovine serum. The cells were trypsinized and seeded at a density of 500 cells per $\mathrm{mm}^{2} 1 \mathrm{~d}$ before treatment started.

\section{Transient transfection and dual luciferase assay}

The transfection procedures were performed as previously described (Po et al. 2002b). OR $\alpha$ and $-\beta$ expression and ORE-luciferase reporter plasmids were gifts from Dr D McDonnell (Duke University, NC, USA). HepG2 cells with insignificant expression of OR (Po et al. 2002b), were co-transfected with three different plasmids, namely, ORE-firefly luciferase reporter, OR expression, and Renilla luciferase control plasmids (Promega Corp., Madison, WI, USA). Lipofectamine (Invitrogen Life Technologies) was used as the agent of transfection. The cells were treated with various concentrations of flavonol and $10^{9} \mathrm{M}-17 \beta$-oestradiol. After $24 \mathrm{~h}$ of treatment, the cells were lysed and assayed for luciferase activities. A dualluciferase reporter assay system from Promega Corp. and a luminometer (FLUOstar Galaxy) were used for this procedure. The reporter firefly luciferase activity was measured by adding Luciferase Assay Reagent II from the kit. The firefly luciferase was then quenched, and the control Renilla luciferase activity was measured. The quantum of light generated from the substrate for the firefly luciferase was an indicator for the OR transactivation activity. The light produced by Renilla luciferase corresponded to the transfection efficiency, and was used for normalization.

\section{Oestrogen receptor element-driven reporter cells assay}

MELN reporter cells were derived from MCF-7 cells by inserting ORE-luciferase reporter genes into the parental cells' genome. These cells could detect OR transactivity in general, but they could not distinguish the interaction from individual isoform. Firefly luciferase activity was measured in cell lysate as described earlier, and the activity was normalized by the protein concentration of the lysate.

\section{Semi-quantitative reverse transcriptase-PCR assay}

Total RNA was isolated from cells grown in six-well Costar plates by a method previously described (Po et al. $2002 a)$. RNA $(1 \mu \mathrm{g})$ was used for cDNA synthesis, and the final volume was diluted to $100 \mu \mathrm{l}$. A reverse transcriptase-PCR assay was used to quantify Bcl-2 mRNA level. Primers of Bcl-2 and $\beta$-actin (sequences published by Wang \& Phang (1995)) were utilized to amplify the target cDNA separately after the first strand reaction. All PCR reactions consisted of $0.2 \mathrm{mmol} \mathrm{dNTP} / \mathrm{l}, 4 \mu \mathrm{l} \mathrm{cDNA}$, $0.2 \mu \mathrm{mol}$ of each primer/l, $1 \times$ PCR buffer and $1 \mathrm{U}$ Taq polymerase. The conditions were $94^{\circ} \mathrm{C}$ for $45 \mathrm{~s}, 65^{\circ} \mathrm{C}$ for $45 \mathrm{~s}, 72^{\circ} \mathrm{C}$ for $2 \mathrm{~min}$, and a final extension period of $7 \mathrm{~min}$ at $72^{\circ} \mathrm{C}$ in a GeneAmp PCR System 2400 thermocycler (Perkin Elmer, Norwalk, CT, USA). The number of amplification cycles were twenty-five for Bcl-2 and nineteen for $\beta$ actin. The PCR products were separated on agarose $(10 \mathrm{~g} / \mathrm{l})$ gel and stained with ethidium bromide. The linearity of signals was verified in separate experiments. 


\section{Western analysis}

Cells were washed once by PBS (pH 7.4) and harvested into a $1.5 \mathrm{ml}$ microtube with $0.5 \mathrm{ml}$ lysis buffer (PBS, $10 \mathrm{~g}$ polyethylene glycol- $p$-isooctylphenyl ether/l, $50 \mathrm{~g}$ sodium deoxycholate/l, $10 \mathrm{~g}$ SDS/l). The lysis buffer contained protease inhibitors (40 mg phenylmethylsulfonyl fluoride/l, $0.5 \mathrm{mg}$ aprotinin $/ 1, \quad 0.5 \mathrm{mg}$ leupeptin/l, $1.1 \mathrm{mmol}$ EDTA/l and $0.7 \mathrm{mg}$ pepstatin/l). The harvested cells were then lysed with a cell disruptor (Branson Ultrasonics Corp., Danbury, CT, USA) on iced water for $30 \mathrm{~s}$. The protein concentration of cell lysate was determined by Dc protein assay (BioRad, Richmond, CA, USA). Lysate protein $(50 \mu \mathrm{g})$ was separated on SDS (100 g/l)-PAGE and transferred to an Immobilon PVDF membrane (Millipore, Bedford, MA, USA). Anti-Bcl-2 (DakoCytomation Denmark A/S, Glostrup, Denmark); anti-actin primary (Sigma Chemical Co.) and secondary antibodies conjugated with horseradish (Armoracia rusticana) peroxidase (Santa Cruz Biotechnology, Santa Cruz, CA, USA), were used for protein detection. An ECL Detection Kit (Amersham, Arlington Heights, IL, USA) provided the chemi-luminence substrate for horseradish peroxidase, and the targeted protein was visualized by autoradiography.

\section{Cell viability and death assay}

A cell death detection ELISA kit was purchased from Roche Molecular Biochemicals (Mannheim, Germany). Cells were incubated in twenty-four-well plates. After $48 \mathrm{~h}$ of treatment, the cells were washed once with PBS and lysed with $0.5 \mathrm{ml}$ lysis buffer provided in the kit. The amount of DNA fragmentation was then quantified in the cell lysates by ELISA. An identically treated culture plate was used for the cell viability determination by 3-(4,5-dimethylthiazol-2-yl)-2,5-diphenyltetrazolium bromide assay (Mosmann, 1983). The relative apoptotic value was then obtained by normalizing the ELISA absorbance with the cell viability (3-(4,5-dimethylthiazol2-yl)-2,5-diphenyltetrazolium bromide absorbance) reading.

\section{Statistical methods}

A Prism 3.0 software package (GraphPad Software, Inc., San Diego, CA, USA) was utilized for statistical analysis. The results, whenever applicable, were analysed by ANOVA. Significant level was set at $P<0 \cdot 05$. The median inhibitory concentrations $\left(\mathrm{IC}_{50}\right)$ for $\mathrm{OR} \alpha$ competition assay were estimated by 'one-site competition' curve-fitting program installed in the software package.

\section{Results}

\section{Oestrogen receptor competition assay}

Quercetin and kaempferol competed with oestrogen for $\mathrm{OR} \alpha$ binding in a cell-free assay system (Fig. 1), and the estimated $\mathrm{IC}_{50}$ were 41 and $38 \mu \mathrm{mol} / 1$ respectively. Compared with the $\mathrm{IC}_{50}$ of unlabelled $17 \beta$-oestradiol, the flavonols were about 2500 -fold weaker for the binding affinity towards the $\mathrm{OR} \alpha$.

\section{Oestrogenic or anti-oestrogenic activity of flavonols in HepG2 cells expressing OR $\alpha$ or $-\beta$}

Because receptor competition was observed in the cell-free binding assay, the interaction between the flavonols and the specific OR isoform was further investigated in HepG2 cells. $0,5,10$ and $25 \mu \mathrm{mol}$ flavonols/l were administered in HepG2 cells expressing either OR $\alpha$ or $-\beta$. Quercetin and kaempferol exhibited agonistic effects on both isoforms (Fig. 2(a and b). When $10^{9} \mathrm{M}$-oestradiol was coadministered, the flavonols could not suppress the induced OR transactivation mediated by $\mathrm{OR} \alpha$ or $-\beta$ (Fig. 3(a and b).

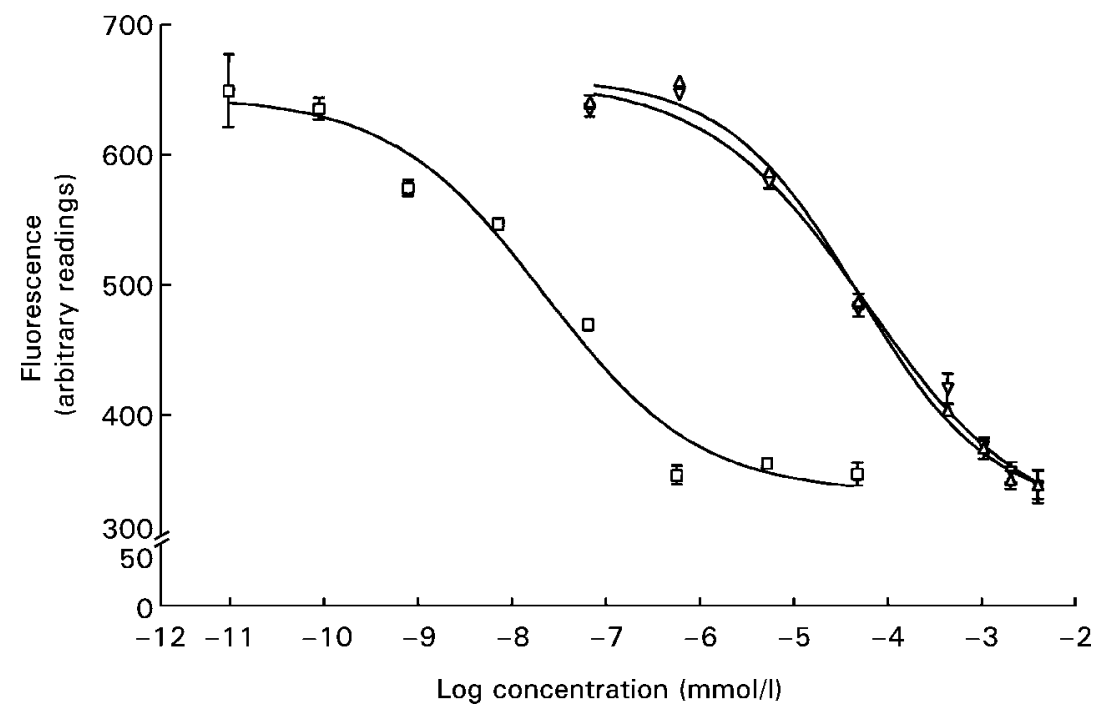

Fig. 1. Competition between flavonols and fluorescein-labelled $17 \beta$-oestradiol for oestrogen receptor $\alpha$ binding. Varying concentrations of quercetin and kaempferol were incubated with $1 \mathrm{~nm}$-fluorescein-labelled $17 \beta$-oestradiol on an oestrogen receptor $\alpha$-coated plate. $\square$, Oestradiol; $\triangle$, quercetin; $\nabla$, kaempferol. For details of procedures, see p. 832. Values are means with their standard errors shown by vertical bars ( $n 3$ ). 


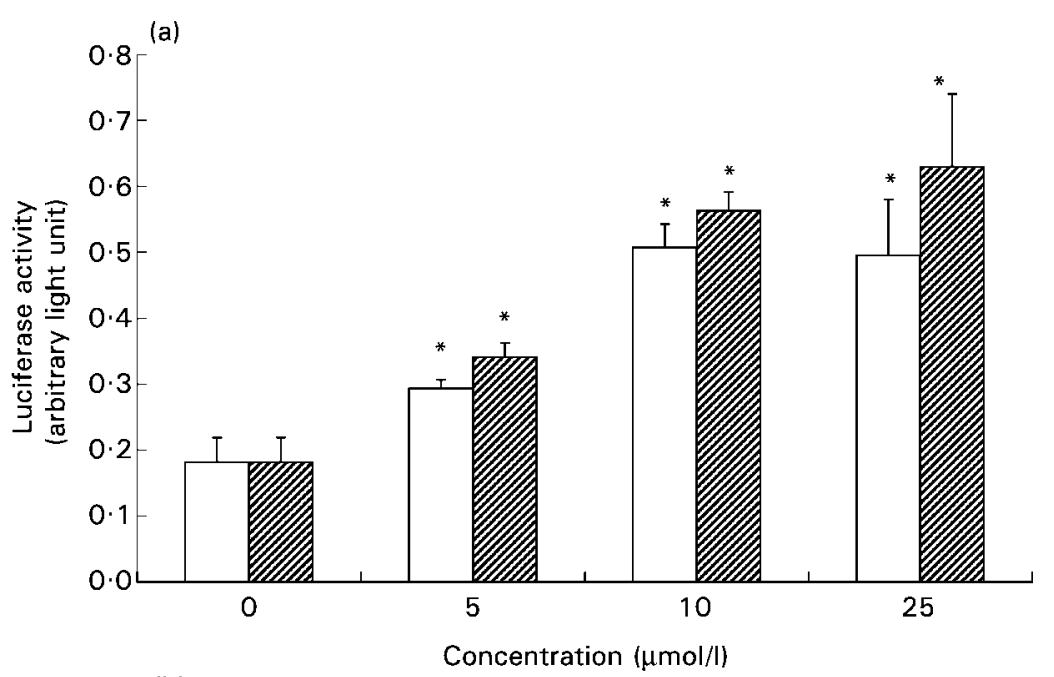

(b)

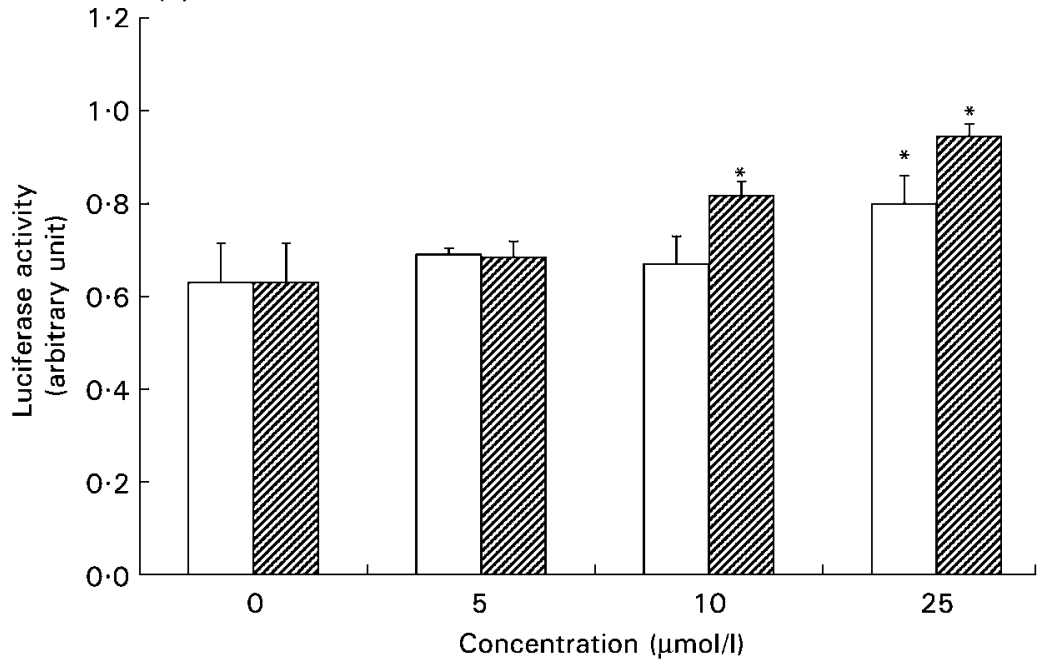

Fig. 2. Effect of flavonols on oestrogen receptor $\alpha$ transactivation activities. HepG2 cells were seeded in twenty-four-well culture plates and transient transfected with oestrogen receptor $\alpha$ expression, control and oestrogen response element-luciferase reporter plasmids for $6 \mathrm{~h}$.

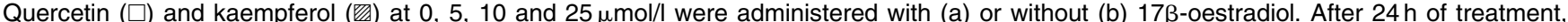
cells were lysed and assayed for dual luciferase activities. For details of procedures, see p. 832. Values are means with their standard deviations shown by vertical bars $(n 3)$. Mean values were significantly had significantly greater transactivation signals than the control $(0 \mu \mathrm{mol} / \mathrm{l}$; ANOVA): ${ }^{\star} P<0.05$.

Flavonol-activated oestrogen response element-luciferase activity in MELN reporter cells

As no anti-oestrogenic effect of the flavonols was observed on the OR isoforms expressed in HepG2 cells, the OR transactivation in MCF-7 cells was examined. Quercetin and kaempferol induced ORE-driven luciferase transcriptional activity at 1,10 and $50 \mu \mathrm{mol} / \mathrm{l}$ as shown in Fig. 4. Judging by the luciferase activity, the flavonols were consistently less oestrogenic than genistein at all the concentrations tested $(P<0 \cdot 05)$.

\section{Bcl-2 mRNA and protein expression}

Bcl-2 controls apoptosis and is responsive to oestrogen as described on p. 832. Since kaempferol and quercetin activated $\mathrm{OR}, \mathrm{Bcl}-2$ expression positioned in the downstream of OR transactivation was investigated. There was an increasing trend in the mRNA abundance semi-quantified by reverse transcriptase-PCR (Fig. 5(a)). Western blot assay indicated that kaempferol and quercetin induced Bcl-2 expression starting at 0.1 and $1.0 \mu \mathrm{mol} / \mathrm{l}$ respectively (Fig. 5(b)).

\section{MCF-7 cell proliferation and death assay}

As both dietary flavonols induced Bcl-2 expression and Bcl-2 is a determining factor of cell death (Reed, 1998; Gross et al. 1999), the issue of whether the increased Bcl-2 expression would affect apoptosis was studied. A proliferative phase was observed in MCF-7 cells treated with genistein, quercetin and kaempferol (Fig. 6(a)). Genistein treatment as low as $0 \cdot 1 \mu \mathrm{mol} / \mathrm{l}$ could induce significant cell proliferation and the same was observed at $1.0 \mu \mathrm{mol} / \mathrm{l}$ for quercetin and kaempferol. Genistein appeared to be the strongest proliferative flavonoid among the three tested. Cell death ELISA assay showed 
(a)

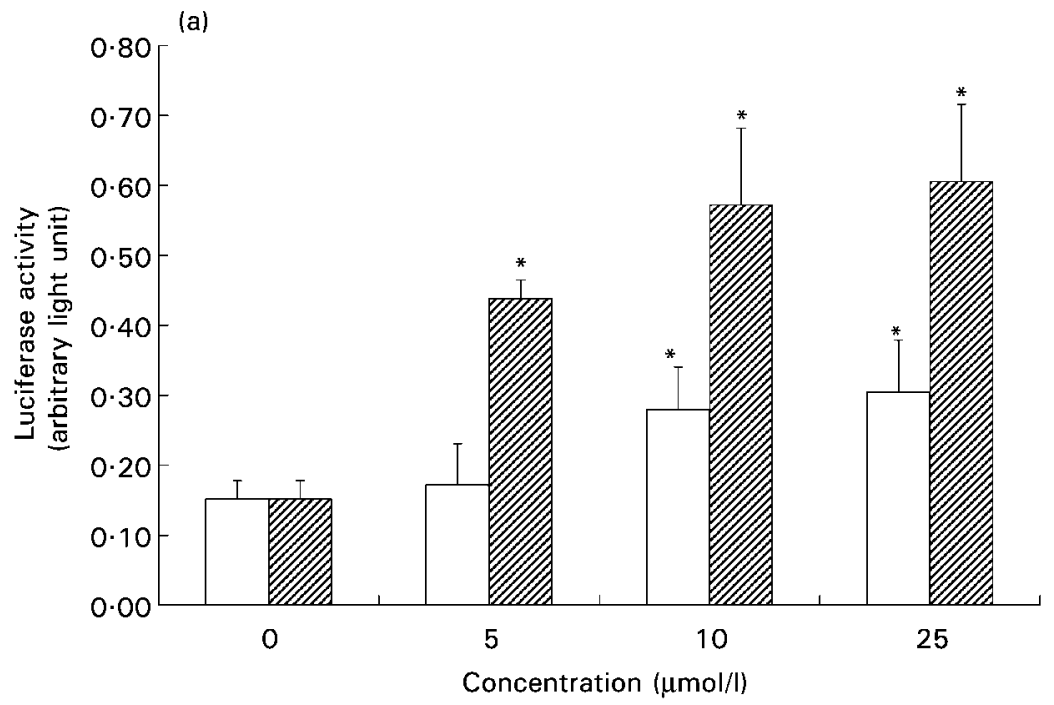

(b)

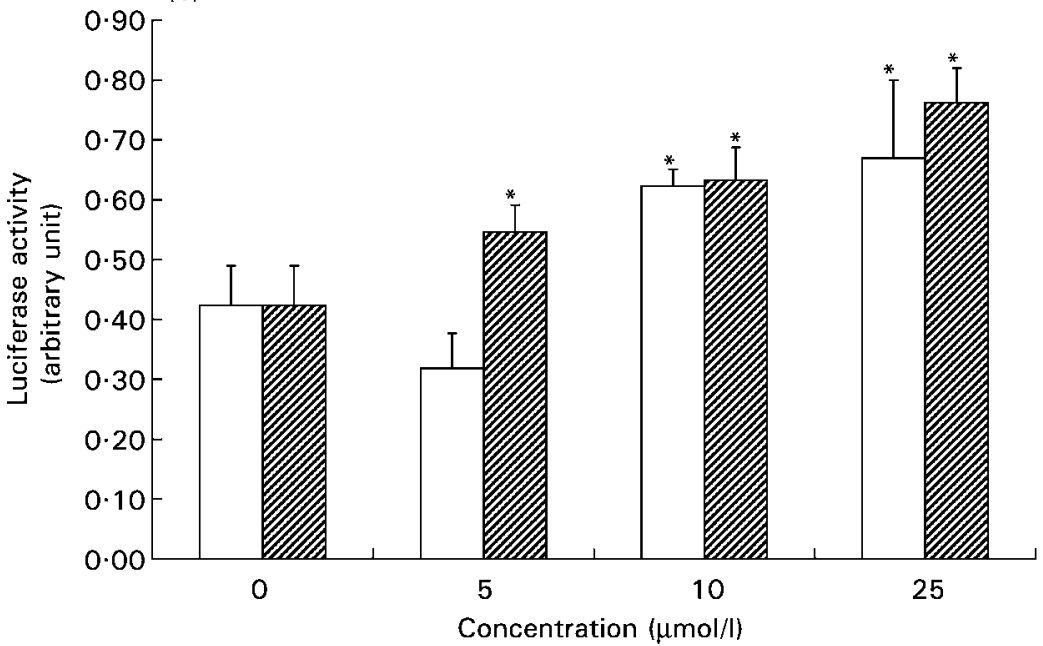

Fig. 3. Effect of flavonols on oestrogen receptor $\beta$ transactivation activities. HepG2 cells were seeded in twenty-four-well culture plates and transient transfected with oestrogen receptor $\beta$ expression, control and oestrogen response element-luciferase reporter plasmids for $6 \mathrm{~h}$.

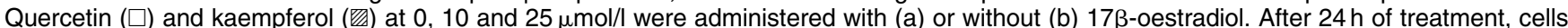
were lysed and assayed for dual luciferase activities. For details of procedures, see p. 833. Values are means with their standard deviations shown by vertical bars $(n=3)$. Mean values were significantly had significantly higher transactivation signals than the control $(0 \mu \mathrm{mol} / \mathrm{l}$; ANOVA): ${ }^{*} P<0.05$.

that the flavonol-treated cultures had greater $(P<0.05)$ amount of DNA fragmentation than the control at $25 \mu \mathrm{mol} / \mathrm{l}$ (Fig. 6(b)).

\section{Discussion}

In the present study, the dietary flavonols quercetin and kaempferol were able to activate both $\mathrm{OR} \alpha$ and $-\beta$, while they did not antagonize $17 \beta$-oestradiol-induced $\mathrm{OR} \alpha$ and $-\beta$ transactivations. Like genistein (Po et al. 2002a), the administration of these flavonols to MCF-7 cells could stimulate the gene expression driven by ORE in spite of the competition for binding to OR in the cell-free assay. Since Bcl-2 is an anti-apoptotic protein that bears two functional ORE in its promoter region (Perillo et al. 2000), its expression can be a counteracting factor of programmed cell death induced by the flavonols. In subsequent experiments, we demonstrated that the dietary flavonols could increase Bcl-2 mRNA and protein expressions, and the outcome was consistent with the OR transfection results. Since $\mathrm{Bcl}-2$ is a major factor in cell survival, alteration in $\mathrm{Bcl}-2$ may redirect the signal of apoptosis. However, the relative apoptotic values indicated that both flavonols induced cell death at $25.0 \mu \mathrm{mol} / \mathrm{l}$, despite the increased expression of $\mathrm{Bcl}-2$. These results illustrated that the dietary flavonols induced cell death and activated the OR transactivation at the same time.

Long-term exposure to oestrogen has been associated with breast cancer because of its ability to cause cell proliferation (Nenci et al. 1988). Many studies have shown that flavonoids have a biphasic effect on MCF-7 cell death (Peterson \& Barnes, 1991; So et al. 1997; Breinholt \& Larsen, 1998; Le Bail et al. 1998). In these studies the proliferating phase is believed to be under the influence of oestrogen-like activity of the phyto-oestrogens, while their anti-oestrogenic activity controls the cytotoxic 


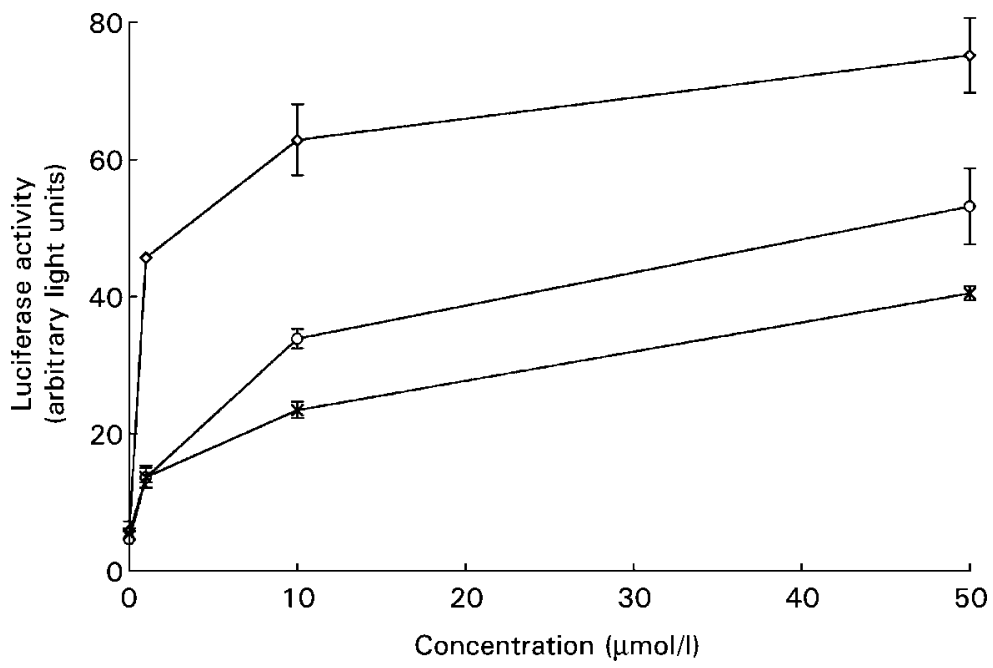

Fig. 4. Effect of flavonols on oestrogen element response-driven luciferase activity in MELN cells. MELN cells were treated with $0,1,10$ and $50 \mu \mathrm{mol}$ genistein $(-\diamond-)$, quercetin $(-\times-)$ or kaempferol $(-O-) / /$ for $48 \mathrm{~h}$. Cell lysates were extracted from the cultures and firefly luciferase activities were determined. All treatment cultures had greater luciferase activity than the control. For details of procedures, see p. 834 . Values are means with their standard errors shown by vertical bars $(n 4)$.

(a)

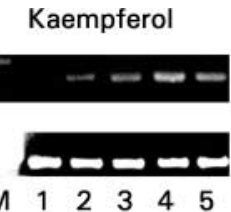

(b)

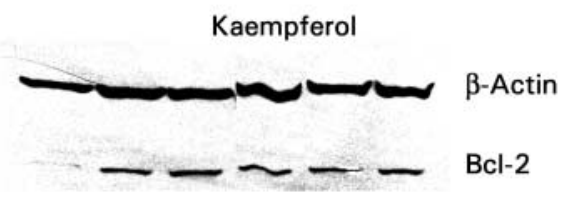

Quercetin

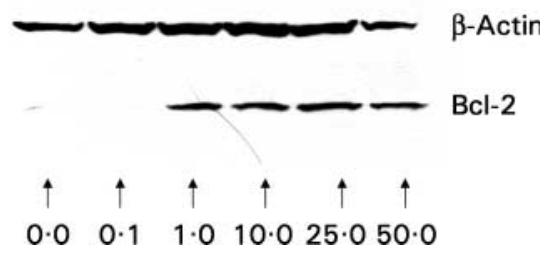

Fig. 5. Effect of flavonols on the mRNA and protein expressions of $\mathrm{Bcl}-2$ in MCF-7 cells. MCF-7 cells were treated with quercetin and kaempferol for $48 \mathrm{~h}$. mRNA and cell lysates were extracted from the cultures, and semi-quantitative reverse transcriptase-PCR reactions and Western blotting were performed to determine the mRNA and protein expressions. The Bcl-2 amplified fragments were visualized by ethidium bromide staining (a). Lane M, DNA marker; lane 1, control culture treated with the carrier solvent; lanes 2, 3 and 4, cells treated with $1,5,10$ and $25 \mu \mathrm{mol}$ quercetin or kaempferol/l. The gel photo is one of three independent experiments with comparable results. Bcl-2 protein expression was quantified by Western analysis with ECL detection (b). Lanes labelled as $0.0,0.1,1.0$, $10.0,25.0,50.0$ are the respective concentrations in $\mu \mathrm{mol} / \mathrm{l}$. For details of procedures, see p. 834. The gel images represent one of two independent experiments.

phase. By contrast, Maggiolini et al. (2001) have suggested that the $\mathrm{OR} \alpha$-dependent pathway is only responsible for the proliferative phase; the OR agonistic nature of genistein and quercetin encourage cell growth at low concentrations, but the antagonistic pathway seemed to be not involved in the cytotoxic phase. The results of the present study appeared to be consistent with these findings. All three flavonoids tested could induce cell proliferation with concentrations ranging from 0.1 to $1.0 \mu \mathrm{mol} / \mathrm{l}$. Among the tested compounds, genistein displayed the greatest potency in OR transactivity and the strongest proliferative effects on MCF-7 cells. In contrast, Miodini et al. (1999) have shown that quercetin does not encourage MCF-7 cell growth in a $7 \mathrm{~d}$ experiment. Different incubation periods could be the cause of the variation observed in these two studies.

Our laboratory has earlier reported that genistein and baicalein have different actions on OR transactivation (Po et al. 2002a). The tested flavonols resemble genistein and baicalein in their chemical structure. The results of the present study supported the notion that the effects of quercetin and kaempferol were similar to that of genistein on OR transactivation. Miodini et al. (1999) have also observed that genistein and quercetin fail to compete with $17 \beta$-oestradiol for OR-ORE complex formation and are able to form OR-ORE complexes by themselves in a gel mobility shift assay.

Oestrogen has been described as inducing OR-positive cell proliferation by up-regulating Bcl-2 without affecting Bax expression (Wang \& Phang, 1995). With two ORE located in the $b c l-2$ promoter region (Perillo et al. 2000), the flavonols in the present investigation could increase Bcl-2 expression through this ORE-dependent pathway. Because of the anti-apoptotic nature of Bcl-2, this finding provided a possible explanation for the cell proliferation induced by low quercetin concentrations observed in the present study and that of Maggiolini et al. (2001).

The effect of quercetin and kaempferol on OR transactivation and programmed cell death in vivo is unclear. Morand et al. (2000) have indicated that the hydrolysed concentration of quercetin in rat plasma can be as great as $11.2 \mu \mathrm{M}$ after providing $20 \mathrm{mg}$ quercetin equivalent in the feed. Cermak et al. (2003) and Sesink et al. (2001) 
(a)

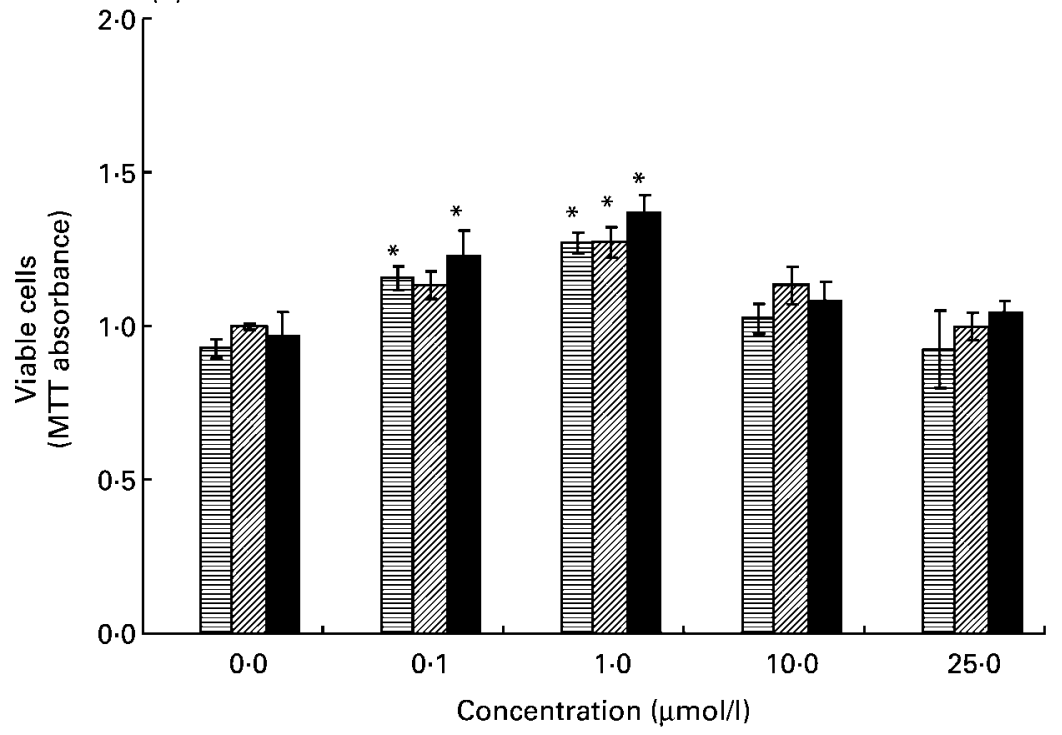

(b)

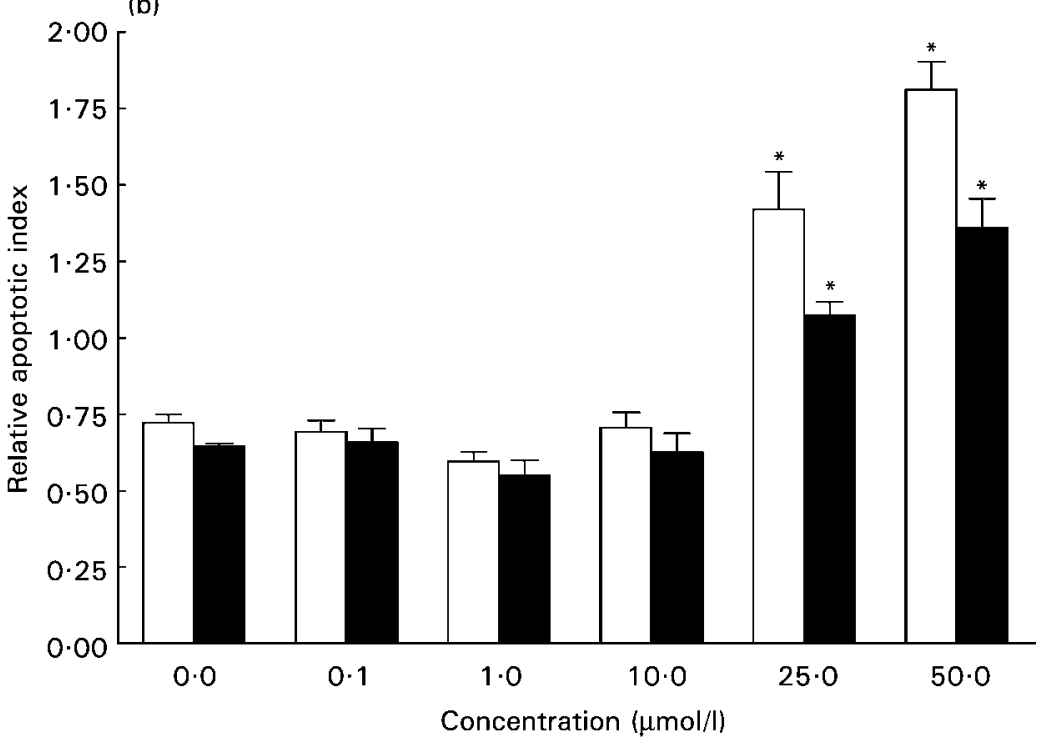

Fig. 6. Cell viability and death assay for MCF-7 cells treated with flavonols. Cells were treated with quercetin and kaempferol at concentrations of $0.0,0.1,1 \cdot 0,10.0$ and $50.0 \mu \mathrm{mol} / /$ for $48 \mathrm{~h}$. The viable cells were quantified by 3-4,5-dimethylthiazol-2-yl)-2,5-diphenyltetrazolium bromide (MTT) assay (a) and DNA fragmentation was measured by an ELISA kit as described on p. 834 (目, quercetin; 㘬, kaempherol; $\mathbf{\square}$, genistein). Relative apoptotic values (b) were the absorbance values representing the amount of DNA fragmentation normalized with the corresponding MTT absorbances ( $\square$, quercetin; $\mathbf{a}$, kaempherol). For details of procedures, see p. 4. Values are means with their standard errors shown by vertical bars $(n 4)$. Mean values were significantly different from each other at each concentration (AVOVA): $P<0.05$.

have not detected any aglycone quercetin in blood after ingesting quercetin or its glucoside in pigs and human subjects. The vast majority of quercetin is in its gluconidated forms. The bioavailability of kaempferol, on the other hand, has not been as well studied as quercetin. Although aglycone forms of kaempferol and quercetin were used in the present study, we speculated that the active moieties could be different from the aglycone forms. From separate experiments we also demonstrated UDP-glucuronosyltransferase activity in this cell model.

At the concentration of $25 \mu \mathrm{mol} / \mathrm{l}$, the flavonols could induce apoptosis though the OR transactivation machinery was still activated and $\mathrm{Bcl}-2$ expression stood at an increased level. This illustrated that the death-inducing mechanism might be independent of the OR transactivation pathway. Choi et al. (2001) demonstrated that quercetin may inhibit MCF-7 cell growth by two mechanisms: induction of apoptosis through p21CIP1/WAF1 pathway and inhibition of cell cycle progression. Soleas et al. (2001) further illustrated that the growth inhibition pathway does not affect p53 expression.

In conclusion, we have demonstrated that apoptosis induced by the dietary flavonols accompanying increases of OR transactivation and $\mathrm{Bcl}-2$ expression. It was not determined whether these pathways were exclusive to each other. However, the present study does not support 
the hypothesis that quercetin or kaempferol were OR antagonists.

\section{Acknowledgements}

This work was supported by the Chinese University of Hong Kong Direct Grant for Research, code 2041031. The authors thank Dr V. C. Jordan of Northwestern University for providing the MCF-7 cells; Dr D. McDonnell of Duke University for the OR expression and reporter plasmids; Ms Susan Ross of CIIT for her excellent technical assistance.

\section{References}

Akagi K, Hirose M, Hoshiya T, Mizoguchi Y, Ito N \& Shirai T (1995) Modulating effects of ellagic acid, vanillin and quercetin in a rat medium term multi-organ carcinogenesis model. Cancer Lett 94, 113-121.

Breinholt V \& Larsen JC (1998) Detection of weak estrogenic flavonoids using a recombinant yeast strain and a modified MCF7 cell proliferation assay. Chem Res Toxicol 11, 622-629.

Cermak R, Landgraf S \& Wolffram S (2003) The bioavailability of quercetin in pigs depends on the glycoside moiety and on dietary factors. J Nutr 133, 2802-2807.

Chan HY, Wang H, Tsang DSC, Chen Z-Y \& Leung LK (2003) Screening of chemopreventive tea polyphenols against PAH genotoxicity in breast cancer cells by a XRE-Luciferase reporter construct. Nutr Cancer 46, 93-100.

Choi JA, Kim JY, Lee JY, Kang CM, Kwon HJ, Yoo YD, Kim TW, Lee YS \& Lee SJ (2001) Induction of cell cycle arrest and apoptosis in human breast cancer cells by quercetin. Int $J$ Oncol 19, 837-844.

Ciolino HP, Daschner PJ \& Yeh GC (1999) Dietary flavonols quercetin and kaempferol are ligands of the aryl hydrocarbon receptor that affect CYP1A1 transcription differentially. Biochem J 340, 715-722.

Collins-Burow BM, Burow ME, Duong BN \& McLachlan JA (2000) Estrogenic and antiestrogenic activities of flavonoid phytochemicals through estrogen receptor binding-dependent and -independent mechanisms. Nutr Cancer 38, 229-245.

Cummings SR, Eckert S, Krueger KA, Grady D, Powles TJ, Cauley JA, Norton L, Nickelsen T, Bjarnason NH, Morrow M, et al. (1999) The effect of raloxifene on risk of breast cancer in postmenopausal women: results from the MORE randomized trial. Multiple Outcomes of Raloxifene Evaluation. $J$ Am Med Assoc 281, 2189-2197.

Davis SR, Dalais FS, Simpson ER \& Murkies AL (1999) Phytoestrogens in health and disease. Recent Prog Horm Res 54, $185-210$.

de Vries JH, Hollman PC, Meyboom S, Buysman MN, Zock PL, van Staveren WA \& Katan MB (1998) Plasma concentrations and urinary excretion of the antioxidant flavonols quercetin and kaempferol as biomarkers for dietary intake. Am J Clin Nutr 68, 60-65.

Dechering K, Boersma C \& Mosselman S (2000) Estrogen receptors alpha and beta: two receptors of a kind? Curr Med Chem 7, 561-576.

Delmas PD, Bjarnason NH, Mitlak BH, Ravoux AC, Shah AS, Huster WJ, Draper M \& Christiansen C (1997) Effects of raloxifene on bone mineral density, serum cholesterol concentrations, and uterine endometrium in postmenopausal women. $N$ Engl J Med 337, 1641-1647.

Gonzalez FJ (2001) The use of gene knockout mice to unravel the mechanisms of toxicity and chemical carcinogenesis. Toxicol Lett 120, 199-208.

Goodman MT, Wilkens LR, Hankin JH, Lyu LC, Wu AH \& Kolonel LN (1997) Association of soy and fiber consumption with the risk of endometrial cancer. Am J Epidemiol 146, 294-306.

Gross A, McDonnell JM \& Korsmeyer SJ (1999) Bcl-2 family members and the mitochondria in apoptosis. Genes Dev 13, 1899-1911.

Han D, Tachibana H \& Yamada K (2001) Inhibition of environmental estrogen-induced proliferation of human breast carcinoma MCF-7 cells by flavonoids. In Vitro Cell Dev Biol Anim 37, 275-282.

Hollman PC \& Katan MB (1999) Dietary flavonoids: intake, health effects and bioavailability. Food Chem Toxicol 37, 937-942.

Ingram D, Sanders K, Kolybaba M \& Lopez D (1997) Case-control study of phyto-oestrogens and breast cancer. Lancet 350 , 990-994.

Kuiper GJM, Carlsson B, Grandien K, Enmark E, Haggblad J \& Gustafsson J-K (1997) Comparison of the ligand binding specificity and transcript tissue distribution of estrogen receptors $\alpha$ and $\beta$. Endocrinology 138, 863-870.

Le Bail JC, Varnat F, Nicolas JC \& Habrioux G (1998) Estrogenic and anti-proliferative activities on MCF-7 human breast cancer cells by flavonoids. Cancer Lett 130, 209-216.

Lee MM, Lin SS, Wrensch MR, Adler SR \& Eisenberg D (2000) Alternative therapies used by women with breast cancer in four ethnic populations. $J$ Natl Cancer Inst 92, 42-47.

Linford NJ \& Dorsa DM (2002) 17beta-Estradiol and the phytoestrogen genistein attenuate neuronal apoptosis induced by the endoplasmic reticulum calcium-ATPase inhibitor thapsigargin. Steroids 67, 1029-1040.

Lowe SW \& Lin AW (2000) Apoptosis in cancer. Carcinogenesis 21, 485-495.

Maggiolini M, Bonofiglio D, Marsico S, Panno ML, Cenni B, Picard D \& Ando S (2001) Estrogen receptor $\alpha$ mediates the proliferative but not the cytotoxic does-dependent effects of two major phytoestrogens on human breast cancer cells. $\mathrm{Mol}$ Pharmacol 60, 595-602.

Matsukawa Y, Nishino H, Okuyama Y, Matsui T, Matsumoto T, Matsumura S, Shimizu Y, Sowa Y \& Sakai T (1997) Effects of quercetin and/or restraint stress on formation of aberrant crypt foci induced by azoxymethane in rat colons. Oncology 54, $118-121$.

Miodini P, Fioravanti L, Di Fronzo G \& Cappelletti V (1999) The two phyto-oestrogens genistein and quercetin exert different effects on oestrogen receptor function. $\mathrm{Br} J$ Cancer $\mathbf{8 0}$, $1150-1155$.

Morand C, Manach C, Crespy V \& Remesy C (2000) Quercetin 3O-beta-glucoside is better absorbed than other quercetin forms and is not present in rat plasma. Free Radic Res 33, 667-676.

Mosmann T (1983) Rapid colorimetric assay for cellular growth and survival: application to proliferation and cytotoxicity assays. J Immunol Methods 65, 55-63.

Nenci I, Marchetti E \& Querzoli P (1988) Commentary on human mammary preneoplasia. The estrogen receptor-promotion hypothesis. J Steroid Biochem 30, 105-106.

Perillo B, Sasso A, Abbondanza C \& Palumbo G (2000) $17 \beta$ estradiol inhibits apoptosis in MCF-7 cells, inducing bcl-2 expression via two estrogen-responsive elements present in the coding sequence. Mol Cell Biol 20, 2890-2901.

Peterson G \& Barnes S (1991) Genistein inhibition of the growth of human breast cancer cells: independence from estrogen receptors and the multi-drug resistance gene. Biochem Biophys Res Comm 179, 661-667.

Po LS, Chen Z-Y, Tsang DSC \& Leung LK (2002a) Baicalein 
and genistein display differential actions on estrogen receptor (ER) transactivation and apoptosis in MCF-7 cells. Cancer Lett 187, 33-40.

Po LS, Wang TTY, Chen Z-Y \& Leung LK (2002b) Genisteininduced apoptosis in MCF-7 cells involves changes in Bak and Bcl-x without evidence of anti-oestrogenic effects. $\mathrm{Br} \mathrm{J}$ Nutr 88, 463-469.

Reed JC (1998) Bcl-2 family proteins. Oncogene 17, 3225-3236. Sesink ALA, O'Leary KA \& Hollman PCH (2001) Quercetin glucuronides but not glucosides are present in human plasma after consumption of quercetin-3-glucoside or quercetin- $4^{\prime}$-glucoside. J Nutr 131, 1938-1941.

So FV, Guthrie N, Chambers AF \& Carroll KK (1997) Inhibition of proliferation of estrogen receptor-positive MCF-7 human breast cancer cells by flavonoids in the presence and absence of excess estrogen. Cancer Lett 112, 127-133.

Soleas GJ, Goldberg DM, Gras L, Levesque M \& Diamandis EP (2001) Do wine polyphenols modulate p53 gene expression in human cancer cell lines? Clin Biochem 34, 415-420.

Tham DM, Gardner CD \& Haskell WL (1998) Clinical review 97: Potential health benefits of dietary phytoestrogens: a review of the clinical, epidemiological, and mechanistic evidence. J Clin Endocrinol Metab 83, 222-335.

Wang TTY \& Phang JM (1995) Effects of estrogen on apoptotic pathways in human breast cancer cell line MCF-7. Cancer Res 55, 3902-3907. 